\title{
Stand Establishment: The Role of Seedling Size and Winter Injury in Early Growth of Three Perennial Grass Species
}

\author{
RICHARD S. WHITE
}

\section{Abstract}

Winter damage and the subsequent number of viable leaves at the beginning of growth in spring were highly correlated with spring and fall seedling growth in crested wheatgrass, Russian wild ryegrass, and pubescent wheatgrass. As spring leaf numbers on individual plants increased from one to four, there was a corresponding increase in subsequent growth. As winter injury increased, seedling growth was reduced. These results suggest that latesummer seeding in the Northern Great Plains would hasten stand establishment and reduce the length of grazing deferment on newly seeded stands.

Introduced grasses have been widely used to increase herbage production and provide high-quality forage in early spring or late summer when native ranges cannot be readily grazed. They also provide greater management flexibility with respect to more effective utilization of a vailable range resources. In the Northern Great Plains, several studies have established that substantial economic advantage can be realized by using introduced forage species in combination with native range (Kilcher and Lawrence 1979; Smoliak and Slen 1974; Houston and Urick 1972; Lodge 1970; and Hart et al. 1983). Applying these principles to management, however, has been handicapped by limited knowledge of ontogenetic relationships in seedlings and the importance of early seedling growth on stand establishment.

Attainment of a suitable stand for grazing depends upon at least two interrelated constituents. Conditions must be favorable for adequate germination, and seedlings must achieve enough growth so that they are not uprooted by grazing animals. Although many studies have evaluated seeding techniques and factors affecting germination, few studies have examined post-emergent development in seeded stands. Several investigations have identified a variety of factors which operate on an inter-and intraspecific level to affect growth. Such things as soil fertility, soil water, and light among others have been well-defined as influencing growth and phenological development. Heinrichs and Bolton (1950), Evans (1961) and Bryan and McMurphy (1968) studied specific effects of competition on stand development while more general discussions have been provided by Dimbleby (1963) and Milthorpe (1961). However, literature concerning the inherent capacity of a species to develop into a mature stand is lacking. My work is an effort to remedy this deficiency and provide a better understanding of how small individual seedlings grow and mature into established plants.

The specific objectives of the present study were to: (1) determine whether seedling size (viz. leaf number) and winter tissue damage were related to subsequent growth, and (2) define the quantitative relationship between these characteristics. Both spring and fall growth were examined during the first full growing season.

\footnotetext{
The author is a research plant physiologist, U.S Department of Agriculture, Agricultural Research Service, Livestock and Range Research Service, Livestock and Range Research Station, Route 1, Box 2021, Miles City, Montana 59301.

This research is a contribution from the Western Region, U.S. Department of Agriculture, Agricultural Research Service, and Montana Agricultural Experiment Station, Journal Series No. 1082.

Manuscript received March 16, 1983
}

\section{Methods}

This study examined seedling development and stand establishment of Nordan crested wheatgrass (Agropyron desertorum (Fisch.) Schult.), Vinall Russian wild ryegrass (Elymus junceus Fisch.), and Mandan 759 pubescent wheatgrass (Agropyron intermedium subsp. trichophorum (Link) Reichb. ex Hegi). These three species are widely used for range improvement in the Northern Great Plains, and they are commonly seeded in other mesic areas of the Intermountain West. Plots 23 by $90 \mathrm{~m}$ were established with four replications of each species in a randomized complete block design. Commercial seed was planted at a $2.5 \mathrm{~cm}$ depth with a double disk drill. Drill rows were $35 \mathrm{~cm}$ apart. All plots were planted on a summer fallowed, weed-free site under dryland conditions, and plants were not subjected to irrigation.

The three species were planted in 1977 on August 30, September 9 and 28 and October 13 and 26 , to provide seedlings with diverse morphological development before overwintering. Seedling emergence was observed in the fall on plots planted earlier than October 26. Seedlings from the October 26 date emerged the following spring and thereby constituted a dormant seeding. Weather conditions were close to long term averages with respect to precipitation and temperature for the duration of the study, and growing conditions were therefore representative of those normally encountered.

Thirty individual plants of each species were randomly selected and marked with wire loops from each planting date within each of the four replications. Plants that emerged in the fall were marked in November, while seedlings that emerged the following spring were marked in April. Seedlings that emerged the previous fall were examined during the first 2 weeks of April to assess the extent of winter damage. Plants were assigned to one of three damage categories depending upon the amount of dead tissue observed. Plants with less than $5 \%$ leaf tissue mortality were regarded as having sustained no appreciable winter damage; plants with 5 to $24 \%$ leaf tissue mortality were considered to have received light damage; and plants with more than $24 \%$ leaf tissue mortality were classed as moderately damaged. Winter-killed seedlings were eliminated from the study. Winter kill was low, however, occurring in less than $5 \%$ of the smaller marked plants and in none of the plants with more than 2 fall leaves. Additional information on methodology and factors affecting winter injury can be found in White and Currie $(1980,1983)$.

Growth of individually marked plants was determined by measuring the green foliage present in early July and in late October, 1978. These sampling periods therefore estimated spring-summer growth (hereafter referred to as spring growth) as well as fall regrowth following summer dormancy. No livestock grazing was present throughout the study. Growth measurements that were taken on each plant included number of tillers, number of leaves, basal intercept, and dry weight of individual seedlings. One-half of the plants were sampled in July and the other half in October. During both sampling intervals, measurements were obtained only from plant tissue that was green. Brown leaves that had dried up 
were disregarded. The July observations had very little brown tissue, but fall measurements had considerably more since dead spring growth was still present. Growth response was evaluated by standard analysis of variance techniques. Spring leaf number and winter injury were regarded as factors in a $4 \times 3$ factorial arrangement in a randomized block design, and observations were obtained from individually marked plants. Separate analysis of variance tables were determined for each species and growth characteristic. Duncan's multiple range test was used to compare mean values among spring leaf number of winter injury categories when significant $(P<0.05) \mathrm{F}$ values were obtained for main effects in the analysis of variance.

Plants were also assigned to one of three growth categories depending upon the number of green leaves present during the spring or fall measurement periods. Categories were small (1-10 leaves), medium (11-20 leaves), and large (21+ leaves) plants. Chi square analysis was then used to evaluate frequency distribution of plants with respect to the plant growth category and either spring leaf number or winter injury classes. Contingency tables were set up so that individual comparisons could be made as desired for each species.

\section{Results}

When favorable growing temperatures occurred in the spring, seedling sizes varied among the 1800 marked plants, from plants with a single leaf to those with several tillers and leaves. The amount of winter injury also varied considerably among individual plants. Although some of the observed response could be attributed to seeding date, seedling size was considerably more important (White and Currie 1980). The results of this work are therefore interpreted on the latter basis.

Seedling size in early spring had a substantial effect upon subsequent growth in all three species, particularly during the initial spring growth period (Table 1). It also remained an important factor with respect to fall regrowth. Crested and pubescent wheatgrass seedlings had similar numbers of leaves produced from spring growth. In contrast, Russian wild ryegrass seedlings had a much slower growth rate with proportionately fewer plants exceeding 10 leaves by early July.
Evaluation of contingency tables from Chi square analysis showed that the number of early spring leaves had a significant $(P<0.05)$ effect on how many leaves were present by early July. Seedlings that emerged from the October 26 dormant seeding rarely grew more than $\mathbf{2 0}$ leaves, and more commonly they had fewer than 10 leaves (Table 1). All Russian wild ryegrass seedlings that emerged in spring had less than 10 leaves by July. About one-third of the crested and pubescent wheatgrass seedlings that initially had one spring leaf developed more than 10 leaves during spring growth, but this amount of growth was not observed in Russian wild ryegrass unless seedlings began growth as a two-leaf plant. When two or three leaves were present in early spring, about $75 \%$ of both wheatgrass species had more than 10 leaves by early July; and when more than four leaves were present, over $75 \%$ of all plants of each species grew more than 20 leaves.

Fall regrowth following summer dormancy was also related to leaf number at the beginning of spring (Table 1). Crested wheatgrass seedlings showed the most regrowth with respect to leaf number, while Russian wild ryegrass exhibited the least. An overwhelming majority of crested and pubescent wheatgrass seedlings with two or more spring leaves had fall regrowth in excess of 10 leaves, and many had more than 20 . Russian wild ryegrass, in contrast, had fewer new fall leaves. None of the spring-germinated Russian wildrye seedlings exceeded 10 leaves.

The amount of winter damage also significantly $(P<0.05)$ affected both spring and fall leaf number in all three species (Table 2). At least two-thirds of the undamaged seedlings had more than 20 leaves by summer, while only about half of the lightly damaged plants were in the same size category. Most moderately damaged seedlings had less than 10 leaves by July. The effect of winter damage on subsequent spring growth was similar in crested and pubescent wheatgrasses. Progressively fewer leaves grew as winter injury increased. Russian wild ryegrass, however, showed a much greater difference in the amount of leaf growth between undamaged and moderately damaged plants. Approximately $80 \%$ of the undamaged Russian wild ryegrass plants had more than 20 leaves, while about the same proportion of moderately damaged seedlings had fewer than 10 leaves. Only $3 \%$ of the moderately damaged plants had more than 20 leaves. When winter damage exceeded $24 \%$ in all species, there seemed to be relatively little change in the

Table 1. Frequency distribution (\%) of plants according to number of green leaves present in early July (spring growth) and late October (fall regrowth) as related to the number of leaves present at the bejinning of spring. Plants without spring leaves were dormant seeded the preceding fall.

\begin{tabular}{|c|c|c|c|c|c|c|c|c|}
\hline \multirow{2}{*}{$\begin{array}{l}\text { No. of leaves in } \\
\text { early spring }\end{array}$} & \multicolumn{4}{|c|}{$\begin{array}{l}\text { Spring growth category } \\
\text { (plant size) }\end{array}$} & \multicolumn{4}{|c|}{$\begin{array}{c}\text { Fall regrowth category' } \\
\text { (plant size) }\end{array}$} \\
\hline & Small & Medium & Large & Sig. $^{2}$ & Small & Medium & Large & Sig. ${ }^{2}$ \\
\hline $\begin{array}{l}0 \\
1 \\
2 \\
3 \\
4+\end{array}$ & $\begin{array}{r}83 \\
65 \\
27 \\
24 \\
0\end{array}$ & $\begin{array}{l}15 \\
22 \\
29 \\
41 \\
24\end{array}$ & $\begin{array}{r}2 \\
13 \\
44 \\
35 \\
76\end{array}$ & $\begin{array}{l}a \\
b \\
c \\
c \\
d\end{array}$ & $\begin{array}{c}\text { heatgras } \\
64 \\
34 \\
13 \\
0 \\
4\end{array}$ & $\begin{array}{l}20 \\
22 \\
31 \\
29 \\
27\end{array}$ & $\begin{array}{l}16 \\
44 \\
56 \\
71 \\
69\end{array}$ & $\begin{array}{l}a \\
b \\
c \\
c \\
c\end{array}$ \\
\hline $\begin{array}{l}0 \\
1 \\
2 \\
3 \\
4+\end{array}$ & $\begin{array}{r}100 \\
81 \\
65 \\
46 \\
2\end{array}$ & $\begin{array}{r}0 \\
16 \\
31 \\
25 \\
19\end{array}$ & $\begin{array}{r}0 \\
3 \\
4 \\
29 \\
79\end{array}$ & $\begin{array}{l}\mathbf{a} \\
\mathbf{b} \\
\mathbf{b} \\
\mathbf{c} \\
\mathbf{d}\end{array}$ & $\begin{array}{c}\text { d Ryegr } \\
100 \\
77 \\
\mathbf{6 7} \\
\mathbf{3 8} \\
\mathbf{3 2}\end{array}$ & $\begin{array}{r}0 \\
18 \\
22 \\
33 \\
23\end{array}$ & $\begin{array}{r}0 \\
5 \\
11 \\
29 \\
55\end{array}$ & $\begin{array}{r}a \\
b \\
b c \\
c d \\
d\end{array}$ \\
\hline $\begin{array}{l}0 \\
1 \\
2 \\
3 \\
4+\end{array}$ & $\begin{array}{r}73 \\
67 \\
18 \\
24 \\
3\end{array}$ & $\begin{array}{l}21 \\
28 \\
24 \\
35 \\
13\end{array}$ & $\begin{array}{r}6 \\
5 \\
58 \\
41 \\
84\end{array}$ & $\begin{array}{l}\mathbf{a} \\
\mathbf{a} \\
\mathbf{b} \\
\mathbf{b} \\
\mathbf{c}\end{array}$ & $\begin{array}{c}\text { Vheatgra } \\
58 \\
55 \\
20 \\
46 \\
13\end{array}$ & $\begin{array}{l}35 \\
24 \\
41 \\
31 \\
25\end{array}$ & $\begin{array}{l}7 \\
21 \\
39 \\
23 \\
62\end{array}$ & $\begin{array}{r}\mathbf{a} \\
\mathbf{a} \\
\mathbf{b} \\
\mathbf{a b} \\
\mathbf{c}\end{array}$ \\
\hline
\end{tabular}

ISmall, medium and large size plants were classified as having 1-10, 11-20, or $21+$ leaves respectively at the time of measurement.

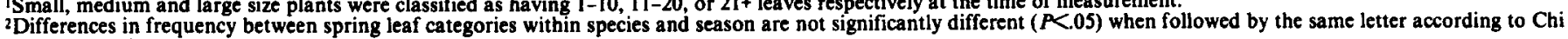
square analysis. 
Table 2. Frequency distribution (\%) of plants according to number of green leaves present in early July (spring growth) and late October (fall regrowth) as related to amount of winter damage.

\begin{tabular}{|c|c|c|c|c|c|c|c|c|}
\hline \multirow{2}{*}{$\begin{array}{l}\text { Winter } \\
\text { damagel }\end{array}$} & \multicolumn{4}{|c|}{$\begin{array}{l}\text { Spring growth category } \\
\text { (plant size) }\end{array}$} & \multicolumn{4}{|c|}{$\begin{array}{c}\text { Fall regrowth category } \\
\text { (plant size) }\end{array}$} \\
\hline & Small & Medium & Large & Sig. $^{3}$ & Small & Medium & Large & $\mathrm{Sig}^{3}$ \\
\hline & \multicolumn{8}{|c|}{ Crested Wheatgrass } \\
\hline none & 7 & 25 & 68 & $\mathbf{a}$ & 1 & 24 & 75 & a \\
\hline light & 18 & 27 & 55 & $\mathrm{a}$ & 14 & 33 & 52 & b \\
\hline \multirow[t]{2}{*}{ mod } & 50 & 28 & 22 & b & 22 & 26 & 52 & b \\
\hline & \multicolumn{8}{|c|}{ Russian Wild Ryegrass } \\
\hline none & 8 & 13 & 79 & a & 12 & 18 & 70 & a \\
\hline light & 24 & 30 & 46 & b & 40 & 31 & 29 & $\mathrm{~b}$ \\
\hline \multirow[t]{2}{*}{$\bmod$} & 78 & 19 & 3 & c & 78 & 17 & 5 & c \\
\hline & \multicolumn{8}{|c|}{ Pubescent Wheatgrass } \\
\hline none & 0 & 12 & 88 & a & 14 & 26 & 60 & $\mathbf{a}$ \\
\hline light & 20 & 20 & 60 & b & 20 & 32 & 48 & a \\
\hline $\bmod$ & 50 & 30 & 20 & c & 46 & 30 & 24 & b \\
\hline
\end{tabular}

'Criteria used to establish winter damage categories are described in the methods section.

2Small, medium and large size plants were classified as having 1-10,11-20, or $21+$ leaves respectively at the time of measurement.

${ }^{3}$ Differences in frequency between winter damage categories are not significantly different $(P<.05)$ when followed by the same letter according to Chi square analysis.

proportion of plants in different leaf categories. This was observed for both spring and fall growth. Consequently, all such plants were combined for analysis purposes and regarded as being moderately damaged.

The effects of winter damage on fall regrowth following fall dormancy were still evident in late October (Table 2). Plants with the greatest winter injury had the fewest fall leaves, and seedlings with no damage had the most. As with summer growth, the impact of winter injury was greatest on Russian wild ryegrass and somewhat less pronounced on crested and pubescent wheatgrasses. About one-half of all damaged crested wheatgrass seedlings had more than 20 fall leaves, but only the lightly damaged pubescent wheatgrass seedlings had that many leaves. About one-fourth of both the lightly damaged Russian wild ryegrass seedlings and the moderately damaged pubescent wheatgrass seedlings had more than 20 leaves. Only $5 \%$ of the moderately damaged Russian wild ryegrass plants had more than 20 leaves. Thus, the relationships between winter damage and fall leaf growth varied among species but were consistent and comparable within each species.

Frequency distributions among the three growth categories indicated that winter damage had the least effect on crested wheatgrass and most effect on Russian wild ryegrass (Table 2). Pubescent wheatgrass was intermediate. This pattern was apparent for both spring and fall growth. Examination of individual growth characteristics showed similar relationships among the three species, and spring growth exceeded fall growth in all species. The number of leaves when growth began also played an important role in determining the relative amount of new tissue growth. Consequently, both winter damage and leaf number were evaluated together as factors contributing to seedling growth.

Winter damage and plant size at the beginning of spring were significantly $(P<0.05)$ related to number of tillers, number of leaves, basal intercept, and plant weight in July and October (Tables 3 and 4). Similar characteristics were observed in all three species although the magnitude of response differed among species.

As anticipated, early growth was greatest for undamaged seedlings with four or more spring leaves (Table 3). It was least for seedlings with one spring leaf and moderate winter damage. Differences between these extremes were considerable. With respect to tillers, for example, crested wheatgrass showed a four-fold difference, while Russian wild ryegrass had an eight-fold difference. Similar comparisons with number of leaves, basal intercept and plant weight showed even greater difference between undamaged large seedlings and moderately damaged small seedlings.
Crested wheatgrass and Russian wild ryegrass seedlings that emerged from the October 26 dormant seeding (i.e., with 0 leaves present in early spring) had less growth by early July than even moderately damaged plants with one leaf (Table 3 ). This was observed with all growth characteristics that were measured. Pubescent wheatgrass seedlings, in contrast, showed relatively more growth in dormant-seeded plants as compared to moderately damaged plants with one leaf. One-leaf plants with light winter damage, however, were able to outgrow dormant-seeded seedlings.

Growth relationships between winter damage and spring plant size can be more easily visualized when they are portrayed graphically (Figure 1). Within any specific spring leaf category, growth

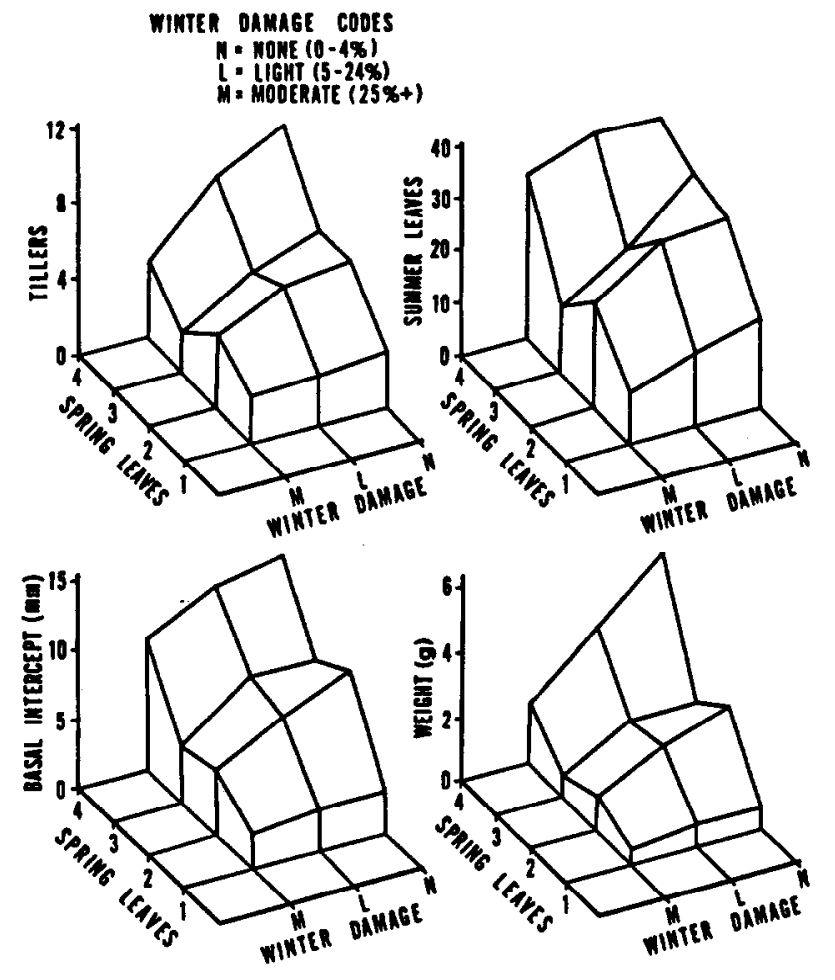

Fig. 1. Spring growth of crested wheatgrass as related to initial seedling size and winter damage. Vertical axes show mean values of individual growth characteristics from about 240 marked plants. 
Table 3. Spring seedling growth as related to winter injury and seedling size at the beginning of spring growth. Plants without spring leaves were dormant seeded the preceding fall.

\begin{tabular}{|c|c|c|c|c|c|c|c|c|c|c|c|c|}
\hline \multirow{3}{*}{$\begin{array}{l}\text { Spring leaf } \\
\text { number }\end{array}$} & \multicolumn{12}{|c|}{ Winter damage ${ }^{2}$} \\
\hline & \multicolumn{4}{|c|}{ Crested wheatgrass } & \multicolumn{4}{|c|}{ Russian wildrye } & \multicolumn{4}{|c|}{ Pubescent wheatgrass } \\
\hline & None & Light & Mod & Average $^{1}$ & None & Light & Mod & Average! & None & Light & Mod & Average 1 \\
\hline & & \multicolumn{3}{|c|}{ Number of tillers } & \multicolumn{5}{|c|}{ Number of tillers } & \multicolumn{3}{|c|}{ Number of tillers } \\
\hline $\mathbf{0}$ & 1.9 & - & - & $1.9 \mathrm{a}$ & 1.1 & - & - & $1.1 \mathrm{a}$ & 1.9 & - & - & $1.9 \mathrm{a}$ \\
\hline 1 & 3.0 & 2.6 & 2.5 & $2.6 \mathrm{ab}$ & 3.0 & 4.1 & 1.4 & $1.8 \mathrm{a}$ & - & 2.0 & 1.8 & $1.8 \mathrm{a}$ \\
\hline 2 & 5.8 & 5.5 & 3.9 & $4.7 c$ & 2.0 & 3.1 & 1.8 & $2.3 \mathrm{ab}$ & 6.8 & 4.6 & 3.5 & $4.5 b$ \\
\hline 3 & 5.8 & 4.4 & 2.2 & $5.0 \mathrm{bc}$ & 4.5 & 4.4 & 1.6 & $3.6 \mathrm{~b}$ & 4.7 & 3.6 & 2.8 & $3.5 \mathrm{ab}$ \\
\hline $4+$ & 9.6 & 7.7 & 4.0 & $8.7 d$ & 10.8 & 7.8 & 6.5 & $8.8 \mathrm{c}$ & 12.3 & 10.6 & 11.0 & $11.3 \mathrm{c}$ \\
\hline \multirow[t]{2}{*}{ Avg1 } & $8.4 \mathrm{a}$ & $5.6 \mathrm{~b}$ & $3.2 \mathrm{c}$ & & $9.5 \mathrm{a}$ & $5.5 \mathrm{~b}$ & $1.8 \mathrm{c}$ & & $5.2 \mathrm{a}$ & $6.7 \mathrm{a}$ & $2.6 \mathrm{~b}$ & \\
\hline & & \multicolumn{3}{|c|}{ Number of leaves } & \multicolumn{5}{|c|}{ Number of leaves } & \multicolumn{3}{|c|}{ Number of leaves } \\
\hline 0 & 9.8 & - & - & $9.8 \mathrm{a}$ & 4.0 & - & - & $4.0 \mathrm{a}$ & $9.1 \mathrm{a}$ & - & - & $9.1 \mathrm{a}$ \\
\hline 1 & 17.4 & 14.2 & 9.8 & $11.6 \mathrm{a}$ & 11.0 & 19.0 & 5.6 & $7.4 \mathrm{ab}$ & - & 10.9 & 8.8 & $9.3 \mathrm{a}$ \\
\hline 2 & 30.3 & 29.2 & 20.4 & $25.0 \mathrm{~b}$ & 6.0 & 12.4 & 8.1 & $9.6 \mathrm{bc}$ & 33.2 & 23.3 & 19.3 & $23.4 b$ \\
\hline 3 & 32.5 & 20.7 & 12.6 & $26.8 \mathrm{bc}$ & 16.5 & 19.4 & 8.3 & $15.9 \mathrm{c}$ & 28.0 & 17.8 & 17.0 & $19.4 \mathrm{ab}$ \\
\hline $4+$ & 36.5 & 37.3 & 32.0 & $36.5 \mathrm{c}$ & 49.6 & 35.0 & 32.8 & $40.3 d$ & 56.9 & 53.3 & 48.3 & $54.6 \mathrm{c}$ \\
\hline \multirow[t]{2}{*}{ Avg } & $35.1 \mathrm{a}$ & $28.3 a$ & $16.1 b$ & & $43.4 \mathrm{a}$ & $24.5 b$ & $7.8 \mathrm{c}$ & & $24.8 \mathrm{a}$ & $34.1 \mathrm{~b}$ & $13.6 \mathrm{c}$ & \\
\hline & \multicolumn{4}{|c|}{ Basal intercept (mm) } & \multicolumn{5}{|c|}{ Basal intercept (mm) } & \multicolumn{3}{|c|}{ Basal intercept (mm) } \\
\hline 0 & 1.8 & - & - & $1.8 \mathrm{a}$ & 1.0 & 一 & - & $1.0 \mathrm{a}$ & 2.3 & - & - & $2.3 \mathrm{a}$ \\
\hline 1 & 3.2 & 3.2 & 2.7 & $2.8 \mathrm{a}$ & 4.0 & 4.8 & 1.7 & $2.1 \mathrm{~b}$ & - & 3.1 & 2.2 & $2.3 \mathrm{a}$ \\
\hline 2 & 9.5 & 7.0 & 4.8 & $6.3 b$ & 1.0 & 3.5 & 2.6 & $2.9 \mathrm{~b}$ & 12.6 & 8.8 & 6.6 & $8.5 b$ \\
\hline 3 & 7.8 & 8.0 & 4.2 & $7.1 \mathrm{~b}$ & 8.5 & 5.9 & 2.3 & $5.0 \mathrm{c}$ & 7.7 & 4.1 & 5.0 & $5.0 \mathrm{ab}$ \\
\hline \multirow{3}{*}{$\begin{array}{r}4+ \\
\text { Avg }\end{array}$} & 13.0 & 12.0 & 9.5 & $12.5 \mathrm{c}$ & 12.8 & 9.0 & 8.0 & $10.4 \mathrm{~d}$ & 19.4 & 15.8 & 11.3 & $17.2 \mathrm{c}$ \\
\hline & $11.4 \mathrm{a}$ & $8.0 \mathrm{~b}$ & $4.1 \mathrm{c}$ & & $11.6 \mathrm{a}$ & $6.6 \mathrm{~b}$ & $2.3 \mathrm{c}$ & & $8.0 \mathrm{a}$ & $10.7 b$ & $3.9 \mathrm{c}$ & \\
\hline & \multicolumn{4}{|c|}{ Plant weight (g) } & \multicolumn{5}{|c|}{ Plant weight (g) } & \multicolumn{3}{|c|}{ Plant weight (g) } \\
\hline 0 & .3 & - & - & $.3 a$ & .0 & - & - & $.0 \mathrm{a}$ & .4 & 一 & 一 & $.4 \mathrm{a}$ \\
\hline 1 & .7 & .6 & .5 & $.6 a b$ & .2 & .5 & .1 & $.1 \mathrm{a}$ & - & .5 & .3 & $.4 \mathrm{a}$ \\
\hline 2 & 2.8 & 2.1 & 1.1 & $1.7 \mathrm{c}$ & .0 & .2 & .1 & $.2 \mathrm{ab}$ & 6.0 & 3.2 & 1.7 & $3.0 \mathrm{~b}$ \\
\hline 3 & 1.5 & 1.5 & .7 & $1.8 \mathrm{bc}$ & .6 & .5 & .1 & $.4 \mathrm{~b}$ & 2.0 & 1.1 & 1.4 & $1.3 \mathrm{ab}$ \\
\hline $4+$ & 5.5 & 3.7 & 1.9 & $4.8 \mathrm{~d}$ & 1.6 & .9 & .5 & $1.2 \mathrm{c}$ & 13.0 & 10.0 & 8.5 & $11.3 \mathrm{c}$ \\
\hline Avg & $4.6 \mathrm{a}$ & $2.3 \mathrm{~b}$ & $.8 \mathrm{c}$ & & $1.4 \mathrm{a}$ & $.1 \mathrm{~b}$ & . Ic & & $4.4 \mathrm{a}$ & $5.6 \mathrm{a}$ & $1.0 \mathrm{~b}$ & \\
\hline
\end{tabular}

'Differences in average values within a row or column within species are not significantly different $(P<.05)$ when followed by the same letter according to Duncan's multiple range test.

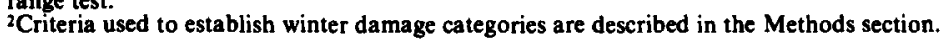

generally increased as winter damage decreased. In a similar fashion, growth within a single damage category increased as spring leaf number increased.

Departure from these general trends can be partially explained by examining interactions. Interactions between variables are illustrated by changes in slope on the growth response surface (Figure 1). Such interactions were significant $(P<0.05)$. The interactions that are presented in Figure 1 showed that changing relationships took place with different variable combinations. Thus, the degree of interaction that was expressed depended upon the quantitative level of independent variables. Interactions appear to be particularly critical with two or three spring leaves and light or no winter damage. Response of Russian wild ryegrass and pubsecent wheatgrass were comparable to those shown with crested wheatgrass.

The number of leaves in early spring had more of an impact on subsequent spring growth than did winter damage, but winter injury was also obviously an important contributor (Figure 1). Both factors were significant $(P<0.05)$ in all three species for all measured growth characteristics. Interpretation of additional three-dimensional graphs from the results presented in Tables 3 and 4 showed similar relationships among variables. However, some differences did exist in magnitude, amplitude, and interactions among variables with respect to species, season, and individual growth characteristics.

Individual fall growth characteristics continued to reflect the effects of spring seedling size and winter damage (Table 4). As with spring growth, larger plants with no injury grew more than smaller plants with greater damage. However, fall growth was less than spring growth, especially with respect to seedlings with more than three spring leaves. Consequently, there was a corresponding reduction in the ratio between moderately damaged seedlings with one spring leaf and undamaged seedlings with four or more leaves. Crested wheat grass, for example, showed about a three-fold difference in number of tillers and plant weight but only about a two-fold difference in number of leaves and basal intercept. Ratios in Russian wild ryegrass and pubescent wheatgrass were likewise reduced although Russian wild ryegrass continued to exhibit the greatest disparity among individual growth traits.

Significant interactions between spring seedling size and winter injury were observed among individual fall growth traits in all three species (Table 4). As with spring growth (Table 3), interactions seemed to affect growth response most when seedlings had two or three spring leaves along with light or no winter injury. However, interactions associated with fall regrowth did not seem to produce as much of a change in plant growth as they did with spring growth. This difference was probably associated with the lower growth rates in the fall.

In general, fall growth showed the same relative relationships among individual growth characteristics as were found in spring growth although overall growth was less (Tables 3 and 4). Seedling size in the spring and winter injury were still correlated with growth response, but the cause-and-effect relationships seemed to be diminished. Crested and pubescent wheatgrasses had more fall regrowth than Russian wild ryegrass, but this could perhaps be more reasonably attributed to maturity differences among species than to seedling factors.

\section{Discussion}

Because seedling size had such a profound effect on subsequent plant development, it would be very advantageous to obtain maximum growth before winter dormancy. This would result in 
Table 4. Fall regrowth in the first growing season as related to winter injury and seedling size at the beginning of spring growth. Plants without spring leaves were dormant seeded the preceding fall.

\begin{tabular}{|c|c|c|c|c|c|c|c|c|c|c|c|c|}
\hline \multirow{3}{*}{$\begin{array}{l}\text { Spring } \\
\text { leaf number }\end{array}$} & \multicolumn{12}{|c|}{ Winter damage ${ }^{2}$} \\
\hline & \multicolumn{4}{|c|}{ Crested wheatgrass } & \multicolumn{4}{|c|}{ Russian wildrye } & \multicolumn{4}{|c|}{ Pubescent wheatgrass } \\
\hline & None & Light & Mod & Average ${ }^{1}$ & None & Light & Mod & Average $^{1}$ & None & Light & Mod & Average $^{1}$ \\
\hline & & \multicolumn{3}{|c|}{ Number of tillers } & \multicolumn{5}{|c|}{ Number of tillers } & \multicolumn{3}{|c|}{ Number of tillers } \\
\hline 0 & 5.8 & - & - & $5.8 \mathrm{a}$ & 1.8 & - & - & $1.8 \mathrm{a}$ & 4.6 & - & - & $4.6 a$ \\
\hline 1 & 10.0 & 8.9 & 10.9 & $10.0 \mathrm{ab}$ & 5.0 & 5.2 & 3.0 & $3.3 \mathrm{a}$ & 5.0 & 9.5 & 4.7 & $5.7 \mathrm{ab}$ \\
\hline 2 & 15.8 & 15.2 & 14.3 & $14.7 \mathrm{bc}$ & 8.0 & 6.1 & 4.1 & $5.0 \mathrm{a}$ & 10.6 & 9.3 & 6.4 & $8.5 b c$ \\
\hline 3 & 17.1 & 15.8 & - & $18.8 \mathrm{~cd}$ & 18.0 & 11.1 & 9.0 & $12.1 \mathrm{~b}$ & 26.3 & 7.4 & 8.0 & $11.8 \mathrm{c}$ \\
\hline $4+$ & 27.9 & 15.5 & 11.0 & $24.6 \mathrm{~d}$ & 23.0 & 7.9 & 2.5 & $14.8 \mathrm{~b}$ & 23.4 & 17.4 & 19.6 & $19.7 \mathrm{~d}$ \\
\hline \multirow[t]{2}{*}{ Avg' } & $25.0 \mathrm{a}$ & $14.0 \mathrm{~b}$ & $14.3 b$ & & $21.4 \mathrm{a}$ & $8.0 \mathrm{~b}$ & $3.6 \mathrm{c}$ & & $18.7 \mathrm{a}$ & $12.7 \mathrm{~b}$ & $6.4 c$ & \\
\hline & & \multicolumn{3}{|c|}{ Number of leaves } & \multicolumn{5}{|c|}{ Number of leaves } & \multicolumn{3}{|c|}{ Number of leaves } \\
\hline 0 & 14.3 & - & - & $14.3 \mathrm{a}$ & 4.1 & - & - & $4.1 \mathrm{a}$ & 10.9 & - & - & $10.9 \mathrm{a}$ \\
\hline 1 & 23.5 & 17.6 & 22.7 & $21.1 \mathrm{ab}$ & 12.0 & 12.8 & 6.3 & $7.2 \mathrm{a}$ & 10.0 & 20.1 & 11.1 & $13.0 \mathrm{a}$ \\
\hline 2 & 30.2 & 30.0 & 25.4 & $27.4 \mathrm{~b}$ & 18.0 & 12.6 & 8.8 & $10.6 \mathrm{a}$ & 25.3 & 22.0 & 14.8 & $20.1 \mathrm{a}$ \\
\hline 3 & 39.3 & 25.1 & - & $34.0 \mathrm{bc}$ & 33.5 & 13.4 & 8.3 & $16.5 a$ & 60.3 & 12.3 & 16.5 & $24.0 \mathrm{a}$ \\
\hline \multirow{3}{*}{$\begin{array}{r}4+ \\
\text { Avg }\end{array}$} & 53.7 & 32.8 & 21.0 & $48.1 \mathrm{c}$ & 49.0 & 19.3 & 2.5 & $32.7 b$ & 46.5 & 41.8 & 45.6 & $44.2 b$ \\
\hline & 49.1a & $27.2 b$ & $25.6 \mathrm{~b}$ & & $45.1 \mathrm{a}$ & $16.0 \mathrm{~b}$ & $7.1 \mathrm{c}$ & & $39.3 \mathrm{a}$ & $29.7 \mathrm{a}$ & $15.0 \mathrm{~b}$ & \\
\hline & & \multicolumn{3}{|c|}{ Basal intercept (mm) } & \multicolumn{4}{|c|}{ Basal intercept (mm) } & & \multicolumn{3}{|c|}{ Basal intercept (mm) } \\
\hline 0 & 7.1 & - & - & $7.1 a$ & 2.2 & - & - & $2.2 \mathrm{a}$ & 7.4 & - & - & $7.4 a$ \\
\hline 1 & 8.0 & 8.2 & 10.6 & $9.4 \mathrm{ab}$ & 5.0 & 6.4 & 4.5 & $4.8 \mathrm{~b}$ & 14.0 & 11.1 & 6.5 & $7.6 \mathrm{a}$ \\
\hline 2 & 12.4 & 12.3 & 14.1 & $13.3 \mathrm{bc}$ & 12.0 & 5.5 & 4.7 & $5.2 \mathrm{~b}$ & 19.4 & 14.7 & 10.4 & $14.1 \mathrm{~b}$ \\
\hline 3 & 14.7 & 18.7 & - & $18.4 \mathrm{~cd}$ & 17.3 & 7.4 & 8.0 & $9.4 c$ & 28.7 & 10.4 & 8.5 & $14.3 \mathrm{ab}$ \\
\hline $4+$ & 22.0 & 11.8 & 12.0 & $19.4 d$ & 16.7 & 11.2 & 2.5 & $13.6 \mathrm{~d}$ & 26.6 & 24.3 & 24.2 & $25.4 c$ \\
\hline \multirow[t]{2}{*}{ Avg } & $19.9 \mathrm{a}$ & $12.3 \mathrm{~b}$ & $13.8 \mathrm{~b}$ & & $16.2 \mathrm{a}$ & $8.7 b$ & $4.7 \mathrm{c}$ & & $24.0 \mathrm{a}$ & $18.1 b$ & $9.1 \mathrm{c}$ & \\
\hline & & \multicolumn{3}{|c|}{ Plant weight $(\mathrm{g})$} & \multicolumn{4}{|c|}{ Plant weight (g) } & \multicolumn{4}{|c|}{ Plant weight (g) } \\
\hline 0 & .2 & - & - & $.2 \mathrm{a}$ & .1 & - & - & $.1 a$ & .3 & - & - & $.3 a$ \\
\hline 1 & .3 & .3 & .4 & $.4 a b$ & .1 & .2 & .1 & $.1 \mathrm{a}$ & .3 & .5 & .4 & $.4 a$ \\
\hline 2 & .5 & .6 & 4 & $.5 \mathrm{~b}$ & 3 & .1 & 1 & la & 1.0 & .7 & .4 & $.7 \mathrm{a}$ \\
\hline 3 & .7 & .7 & - & $.8 \mathrm{bc}$ & .8 & .3 & .3 & $.4 \mathrm{~b}$ & 3.6 & .4 & .1 & $1.1 \mathrm{a}$ \\
\hline $4+$ & 1.0 & .7 & .5 & $.9 c$ & .8 & .5 & .0 & $.6 \mathrm{c}$ & 2.2 & 1.9 & 1.0 & $1.9 \mathrm{~b}$ \\
\hline Avg & $.9 \mathrm{a}$ & $.6 \mathrm{~b}$ & $.5 \mathrm{~b}$ & & $.8 \mathrm{a}$ & $.3 b$ & $.1 \mathrm{c}$ & & $1.9 \mathrm{a}$ & $1.2 \mathrm{~b}$ & $.5 c$ & \\
\hline
\end{tabular}

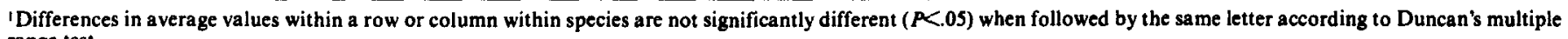
range test.

${ }^{2}$ Criteria used to establish winter damage categories are described in the Methods section.

reduced winter injury (White and Currie 1980) and enhanced spring and fall growth during the first growing season. Consequently, stand development would be more rapid. Even a difference of one or two leaves results in as much as twice the growth depending on the amount of winter injury. Growth of three or more leaves prior to winter dormancy should be the objective for which to strive. Winter damage would be less (White and Currie 1980), and subsequent spring and fall growth would be maximized.

My results show that dormant-seeded plants from late-fall seedings were seldom able to outgrow seedlings that had emerged the preceding fall. Thus, the common practice of late-fall seeding in the Northern Great Plains must be examined. A viable alternative implied by my work would be to prepare the seedbed in the spring, fallow during the summer, and plant in early or mid-September. If late summer precipitation occurs along with favorable temperatures, seeds would germinate and roots would reach the soil moisture retained by fallowing. Seedlings would then have time to produce three or more leaves before the onset of winter. If precipitation is delayed or temperatures are too cool for vigorous growth, seedlings would be correspondingly smaller. However, growth of these seedlings during the following growing season would still be greater than plants from a late-fall, dormant seeding. If no effective late-summer precipitation is received, seeds would not germinate, and the planting would essentially be a dormant seeding. It is very important to recognize, however, that the key to success in this seeding strategy is adequate sub-surface moisture. If the seedbed is poorly prepared or drought conditions prevail, there would be insufficient water stored in the fallowed ground. Seeds that germi nate under such conditions would probably die unless additional precipitation is received. Under such circumstances, it would be better to plan a dormant seeding and plant in late fall.
Most seeding techniques require at least one full season of deferment before grazing and many need two or more (Vallentine 1971). Application of my results, however, indicate that this interval could be effectively reduced in a number of cases. When plants started spring growth with more than three leaves, they were ready to graze by mid-summer. In contrast, plants with fewer than three leaves required an additional year of deferment. From a management standpoint, therefore, tangible economic gains could be realized almost immediately with fall-germinated seedlings. A logical way of receiving the maximum response would be to plant in late summer or early fall as previously outlined. Other benefits such as more rapid soil stabilization and fewer annual weeds could also be associated with this planting strategy.

In summary, my work showed that spring and fall growth in three perennial grass species was affected by winter damage and seedling size at the beginning of spring. Seedling size, as measured by number of leaves, had a greater effect on subsequent growth; however, winter injury could also have a profound effect, especially with respect to smaller seedlings. The relationships among variables were readily quantifiable, and the results have some important management implications concerning seeding practices in the Northern Great Plains. If properly instigated, late summer planting can result in more rapid stand establishment with a corresponding reduction in the length of the grazing deferment period.

\section{Literature Cited}

Bryan, G.G. and W.E. McMurphy. 1968. Competition and fertilization as influences on grass seedlings. J. Range Manage. 21:98-101.

Dimbleby, G.W. 1963. Competition among crop and pasture plants. Adv. Agron. 15:1-118. 
Evans, R.A. 1961. Effects of different densities of downy brome (Bromus tectorum) on growth and survival of crested wheatgrass (Agropyron desertorum) in the greenhouse. Weeds. 9:216-223.

Hart, R.H., J.W. Waggoner, Jr., D.H. Kaltenbach, J.A. Hager, and M.B. Marshall. 1983. Beef cattle performance on crested wheatgrass plus native range vs. native range alone. J. Range Manage. 36:38-40.

Heinrichs, D.H. and J.L. Bolton. 1950. Studies on the competition of crested wheatgrass with perennial native species. Sci. Agr. 30:428-443.

Houston, W.R. and J.J. Urick. 1972. Improved spring pastures, cow-calf production, and stocking rate carryover in the Northern Great Plains. U.S.D.A. Tech. Bull. 145 I.

Kilcher, M.R. and T. Lawrence. 1979. Spring and summer pastures for southwestern Saskatchewan. Can. J. Plant Sci. 59:339-342.

Lodge, R.W. 1970. Complementary grazing systems for the Northern Great Plains. J. Range Manage. 23:268-271.
Milthorpe, F.L. (ed.). 1961. Mechanisms in bioloical competition. Soc. Exp. Biol. Symp. 15.

Smoliak, S. and S.B. Slen. 1974. Beef production on native range, crested wheatgrass and Russian wildrye pastures. J. Range Manage. 27:433-436.

Vallentine, J.F. 1971. Range development and improvements. Brigham Young Univ. Press, Provo, Utah.

White, R.S. and P.O. Currie. 1980. Morphological factors related to seedling injury in three perennial grass species. Can. J. Plant Sci. 60:1411-1418.

White, R.S. and P.O. Currie. 1983. Grass establishment: An evaluation of seedling characteristics relative to winter injury, survival, and early growth. p. 560-563. In: J.A. Smith, and V.W. Hays (eds.) Proc. XIV Internat. Grassland Congress, Lexington, Kentucky, June 15-24, 1981. 